\title{
The Age of Balancing Revisited?
}

\author{
Janneke Gerards*
}

\section{Attractiveness of the Balancing Metaphor}

In 1987, Alexander Aleinikoff famously wrote that we live in an 'age of balancing'. Roughly 30 years later, this still seems to hold true. The European Court of Human Rights (ECtHR) mentions time and again that inherent in the whole of the Convention is a search for a fair balance ${ }^{\prime 2}$ and that it is necessary to strike such a fair balance in cases about conflicting rights or positive obligations. ${ }^{3}$ Even the Court of Justice of the European Union (CJEU), which has long avoided the terminology of balancing, frequently uses balancing language in its more recent case-law on the EU Charter of Fundamental Rights. ${ }^{4}$ For example, confronted with the question of whether search engine Google should be obliged to remove all search results referring to private information about individuals that no longer can be considered relevant, it ruled that:

While the data subject's rights protected by Articles 7 and 8 of the Charter override, as a general rule, the freedom of information of internet users, that balance may, however, depend, in specific cases, on the nature of the information in question and its sensitivity for the data subject's private life and on the interest of the public in having that information, an interest which may vary, in particular, according to the role played by the data subject in public life. ${ }^{5}$

Indeed, the balancing metaphor has a strong intuitive appeal. ${ }^{6}$ It simply feels good to have the image in mind of a judge placing two interests (or rights, or values) in the two scales of a balance, which then tips to one side or the other to provide us with a fair answer. The role of the judge in this image is reduced to the bare minimum. She places

DOI: $10.21552 / \mathrm{edpl} / 2020 / 1 / 5$

* Janneke Gerards is professor of fundamental rights law at Utrecht University (Montaigne Centre for Rule of Law and Administration of Justice); see <https://www.uu.nl/staff/jhgerards>. For correspondence: <j.h.gerards@uu.nl>.

1 Alexander Aleinikoff, 'Constitutional Law in the Age of Balancing' (1987) 96 Yale LJ 943.

2 Eg Soering $v$ UK App no 14038/88 (ECtHR 7 July 1989), para 89.

3 See further, with references, Janneke Gerards, General Principles of the European Convention on Human Rights (CUP 2019$) 242$.

4 See, eg, Case C-345/17 Buivids [2019] ECLI:EU:C:2019:122, para 64; Case C-468/10 ASNEF [2011] ECR I-12181, para 43; Case C-201/13 Deckmyn [2014] ECLI:EU:C:2014:2132, para 27. See also Steven Greer, Janneke Gerards and Rose Slowe, Human Rights in the

Council of Europe and the European Union. Achievements, Trends and Challenges (CUP 2018) 317; Filippo Fontanelli, 'The Mythology of Proportionality in Judgments of the Court of Justice of the European Union on Internet and Fundamental Rights' (2016) 36 OJLS 630, 643; Wolfgang Weiß, 'The EU Human Rights Regime Post Lisbon: Turning the CJEU into a Human Rights Court?' in Sonia MoranoFoadi and Lucy Vickers (eds), Fundamental Rights in the EU. A Matter for Two Courts (Hart 2015) 69, 75.

5 Case C-136/17 GC and Others v Google [2019] ECLI:EU:C:2019:773, para 66; see earlier also Case C-131/12 Google Spain [2014] ECLI:EU:C:2014:317, para 81. 
the interests in the scales, but the actual decision does not seem to be taken by her, but by some external means: the scales. This external means suggests objectivity and neutrality and thus perfectly fits the image that we want to have of judges and courts: They should decide our cases in a neutral, fair and objective manner, without their emotions or personal opinions playing any role at all. ${ }^{7}$ Moreover, the image of balancing fits our understanding of how we make well-considered decisions. By our own experience, we know the 'on the one hand, on the other hand' type of considerations that keep us awake at night when we have to make a difficult choice. Thus, the balancing metaphor is close to how we feel decisions are being made, and this makes it a powerful rhetorical device. ${ }^{8}$

\section{Problems of the Balancing Metaphor}

Nevertheless, the image of neutral balancing is nothing more than a metaphor. ${ }^{9}$ It is hardly realistic to expect that a judge really places two (sets of) interests in the scales of a balance, and it is even more difficult to believe that the scales then tip in the right direction by some force of nature. There are no reliable instruments to determine the weight of intangible matters such as the freedom of information or the right to data protection, ${ }^{10}$ nor is there is any neutral and objective standard to evaluate and compare these interests. ${ }^{11}$ In the end, it is the judge who has to make a choice, and it is unavoidable that this choice is determined by (legally informed) intuition, experience and personal opinion. ${ }^{12}$ Knowing this, it comes as no surprise that it proves to be difficult for judges to translate the image of 'balancing' into convincing and transparent reasoning that allows the reader to understand on what basis a certain decision has been made. In many cases, balancing reasoning comes down to setting out some of the interests involved in a case (usually not even all of them) and then deciding that, all things considered, one outweighs the others.

Such criticism is far from new. Aleinikoff has mentioned these and other important critiques in his article on the age of balancing and many have followed suit. ${ }^{13}$ Indeed, even great supporters of judicial balancing review, such as Robert Alexy, have tried to rationalise balancing by introducing formulas to 'measure' the relative weight of

7 Cf Lon Fuller, 'The Forms and Limits of Adjudication' (1978) 92 Harvard LRev 353, 366.

8 Cf, eg, Jacco Bomhoff, 'Genealogies of Balancing as Discourse' (2010) 4 Law \& Ethics of Human Rights 108, 109; Frederick Schauer, 'Giving Reasons' (1995) 47 Stanford LRev 633, 648.

9 Cf Aleinikoff (n 1) 972; Tsakyrakis (n 1) 470.

10 Aleinikoff (n 1) 973; Fontanelli (n 4) 644.

11 Cf, eg, Stijn Smet, Resolving Conflicts between Human Rights. The judge's dilemma (Routledge 2016); Julian Rivers, 'Proportionality and Variable Intensity of Review' (2006) 65 CLJ 174, 190; John Alder, 'The Sublime and the Beautiful: Incommensurability and Human Rights' (2006) PL 697. Another problem is that many cases involve more than two (sets of) interests; see eg Grégoire Webber, 'Proportionality, Balancing and the Cult of Constitutional Rights Scholarship', (2010) 23 Canadian Journal of Law and Jurisprudence 179

12 Cf, eg, Frederick Schauer, Thinking Like a Lawyer. A New Introduction to Judicial Reasoning (Harvard University Press 2009); Smet (n 11).

13 See the various sources quoted above; see famously also Jürgen Habermas, Between Facts and Norms. Contributions to a Discourse Theory of Law and Democracy (MIT Press, En tr 1996) 259. For a specific critique of balancing in an age of technological innovation, see Fontanelli (n 4) 640; see recently and in great detail also Louis Kaplow, 'On the Design of Legal Rules: Balancing versus Structured Decision Procedures' (2019) 132 Harvard Law Review 992. 
interests and compare them to each other. ${ }^{14}$ Also in legal practice, much work has been done to introduce objectifying factors to improve the transparency of judicial reasoning. For example, the ECtHR has identified sets of factors and standards that can be taken into account in determining the weight of conflicting rights and interests and that can help the reader understand why more weight has been given to, for example, the freedom of expression than to the right to respect for one's privacy in cases where damage has been done to an individual's reputation. ${ }^{15}$ To illustrate, in the second Von Hannover case the ECtHR held that account should be taken of factors such as whether the publication contributed to a debate of general interest, how well-known the person concerned was, what were the content, form and consequences of the publication, and so on. ${ }^{16}$ Similarly, in the quoted GC case the CJEU provided a list of factors a search engine operator should take into account when deciding on whether or not to remove search results. In particular, the CJEU offered additional factors that could be relevant in deciding whether a search operator should be prohibited to display search results referring to websites disclosing that an individual had been the subject of criminal court proceedings. ${ }^{17}$ In this respect the CJEU held that account should be taken of:

... in particular, the nature and seriousness of the offence in question, the progress and the outcome of the proceedings, the time elapsed, the part played by the data subject in public life and his past conduct, the public's interest at the time of the request, the content and form of the publication and the consequences of publication for the data subject .... ${ }^{18}$

Such factors certainly may make it easier to understand how the weight of the various interests is determined and why a decision is made to have one interest prevail over another. ${ }^{19}$ Nevertheless, such lists still leave judges and their audiences with much uncertainty, not in the least about the relative weight of the various factors. Are any of these more important than others? And what if certain factors point in the direction of giving more weight to the freedom of expression or the freedom of information, and other factors in the direction of the right to reputation or data protection? Lists of factors tend not to answer that kind of questions.

Consequently, although balancing might have a strong intuitive appeal, it has significant shortcomings from a perspective of sound judicial argumentation. This, then, raises the question of whether it is possible to avoid balancing in judicial decision-making. Such avoidance strategies indeed exist. ${ }^{20}$

\footnotetext{
14 See in particular Robert Alexy, A Theory of Constitutional Rights (OUP 2002); Robert Alexy, 'Constitutional Rights, Balancing and Rationality' (2003) RJ 131. See also, eg, Matthias Klatt and Moritz Meister, The Constitutional Structure of Proportionality (OUP 2012); Kai Möller, 'Proportionality: Challenging the Critics' (2012) 10 ICON 709-731; Smet (n 11).

15 See further, with references Gerards (n 3) 248

16 Von Hannover v Germany (No. 2) App nos 40660/08 and 60641/08 (ECtHR, 7 February 2012), paras 108-113.

17 GC (n 5)

18 ibid para 77

19 See in particular also Smet (n 11), who strongly advocates such structured judicial balancing review.

20 See also Smet (n 11)
} 


\section{Avoiding Balancing by Categorisation}

First, courts may rely on the technique of categorisation to avoid balancing review. ${ }^{21}$ For certain situation types, they may create a specific test or define a specific set of factors that then can be applied to the facts of the case in a rule-like fashion. A famous example are tests like the 'clear and present danger test' and the 'actual malice test' developed by the US Supreme Court to decide if the freedom of expression can reasonably be restricted in cases on hate speech or damage to one's reputation. ${ }^{22}$ Similarly, the ECtHR often recognises 'general principles' to help it decide on particular types of cases. ${ }^{23}$ For example, in a landmark judgment in the Refah Partisi case, it accepted three standards to determine if a political party advocating a non-democratic society can be prohibited or dissolved. In the Court's view, its assessment in such a case should concentrate on:

(i) whether there was plausible evidence that the risk to democracy, supposing it had been proved to exist, was sufficiently imminent; (ii) whether the acts and speeches of the leaders and members of the political party concerned were imputable to the party as a whole; and (iii) whether the acts and speeches imputable to the political party formed a whole which gave a clear picture of a model of society conceived and advocated by the party which was incompatible with the concept of a 'democratic society'. ${ }^{24}$

The application of these standards does not require any ad hoc balance to be struck between the interests of the freedom of assembly and the public interest of safeguarding a democratic system. Instead, it requires that the ECtHR investigate if it can be sufficiently established that the behaviour of a political party, based on these standards, poses an immediate risk to the protection of the underlying values of the European Convention of Human Rights.

Indeed, there are many cases in which - over time - such 'general principles', tests or standards have been defined and in which ad hoc balancing is no longer needed. ${ }^{25}$ Of course, however, it may be said that this strategy does not help to fully avoid balancing. After all, the initial decision in which the standards or tests are defined almost necessarily reflects a balancing exercise. This is often termed 'definitional balancing' to distinguish this type of balancing from the open, ad hoc balancing in individual cas-

21 See in particular Kathleen Sullivan, 'Foreword: The Justices of Rules and Standards' (1992) 106 Harvard LRev 22; Kathleen Sullivan, 'PostLiberal Judging: The Roles of Categorization and Balancing' (1992) 63 University of Colorado LRev 293; see more recently also Kaplow (n 13) 1055. For a particular variation (the definition of 'exclusionary reasons'), see Richard Pildes, 'Avoiding Balancing: The Role of Exclusionary Reasons in Constitutional Law' (1994) 45 Hastings LJ 711.

22 See respectively Schenck v US, 249 US 47 (1919) 52 and New York Times v Sullivan, 376 US 254 (1964). See further, eg, Eric Barendt, Freedom of Speech (OUP 2007). Similar tests have been developed in relation to privacy and data protection; see eg Axel Tschentscher, 'Privacy and Data Protection by Rules Rather than Principles' (SSRN, 4 August 2017) <https://ssrn.com/abstract=3013830> accessed 29 September 2019

23 See further Gerards (n 3) 37-44; Janneke Gerards, 'Dealing with Divergence. Margin of Appreciation and Incrementalism in the Case-Law of the European Court of Human Rights' (2018) 18 HRLR 495.

24 Refah Partisi (The Welfare Party) and Others v. Turkey, App no 41340/98 (ECtHR, 13 February 2003) para 104.

25 See further, with more examples, Gerards (n 3) 37-44, 232. 
es. ${ }^{26}$ The standards relied on in subsequent cases then simply repeat and reconfirm the balance struck in the original judgment. From a perspective of clarity and openness such definitional balancing might be even worse than ad hoc balancing, since the original balancing exercise is no longer visible in subsequent cases. ${ }^{27}$

Nevertheless, the advantage of categories, rules and standards is that they can be rather clear and precise and it is - at least for lawyers - relatively easy to see how they are applied and for what reason. ${ }^{28}$ Thus, they allow for criticism and they invite substantive changes to be proposed. In the end, this makes judicial reasoning based on standards and categories relatively transparent and therefore, generally, this technique can be preferred over an open, ad hoc balancing approach.

\section{Avoiding Balancing by Procedural Review}

Second, courts may rely on procedural or process-based review. ${ }^{29}$ Balancing review necessitates an assessment of the substance of a conflict of interests: The judge must assess which interests are at stake and how much weight should be accorded to them. As mentioned above, there is no rational standard available for doing so. For that reason, it has been contended that balancing exercises preferably should not be engaged in by courts, but should be made by bodies that have been democratically elected or can be held politically accountable. ${ }^{30}$ Such bodies have both the legitimacy to make moral choices and the capacity to engage in extensive fact-finding, consultation and gathering of information. ${ }^{31}$

In reality, however, politically accountable bodies may not be very much concerned about fact-finding, they may ignore or neglect the interests of specific groups or persons, or they may base a decision on the possibility of political gain rather than wellstated moral grounds. In such cases, a court may decide not to substitute the national authorities' balancing exercise by one of its own, but it may find that the process of decision-making has been flawed and it may find a violation of a fundamental right on that basis. ${ }^{32}$ Similarly, where a sensitive case is concerned an international court may not want to interfere with the outcome that has been reached by a national court. ${ }^{33}$

26 See further Aleinikoff (n 1) 948. See also Mark Kende, 'The Unmasking of Balancing and Proportionality Review in U.S. Constitutional Law' (2017) 25 Cardozo JICL 417, who calls this 'masked balancing' (431)

27 Cf Aharon Barak, Proportionality. Constitutional Rights and their Limitations (CUP 2012) 504-505.

28 Cf also Antonin Scalia, 'The Rule of Law as a Law of Rules' (1989) 56 University of Chicago LRev 1175, 1179.

29 Much has been written on this technique. See recently, with numerous references to other relevant sources, eg, Leonie Huijbers, Process-based Fundamental Rights Review. Practice, Concept, and Theory (Intersentia 2019); Janneke Gerards and Eva Brems (eds), Procedural review in European fundamental rights cases (CUP 2017). Huijbers also provides a comparative review showing that many courts all over the world make use of this technique (see chs 2-4).

30 See further on this, with many references, Huijbers (n 29) ch 9.

31 See further on the debate on this Huijbers (n 29) ch 9.

32 For the distinction between substance- and process-based review, see eg Huijbers (n 29) s 5.3.2; Aruna Sathanapally, 'The Modest Promise of "Procedural Review" in Fundamental Rights Cases' in Gerards and Brems (n 29) 40. For the argument that sensitive balancing can be avoided through procedural review, see eg Patricia Popelier, 'The Court as Regulatory Watchdog: The Procedural Approach in the Case Law of the European Court of Human Rights' in Patricia Popelier et al (eds), The Role of Constitutional Courts in Multilevel Governance (Intersentia 2012 ) 249.

33 This touches the issue of subsidiarity; on this, see eg Eva Brems, 'Positive Subsidiarity and its Implications for the Margin of Appreciation Doctrine' (2019) 37 NQHR, doi:10.1177/0924051919861798. 
Also in that situation it may choose not to re-balance the interests concerned, but to look into whether the procedure before the national courts met all relevant requirements and the national courts took into account all relevant standards. ${ }^{34}$

Thus, procedural review can be a useful avoidance technique, since it allows a court to not engage in balancing and leave the responsibility for doing so with bodies that have the appropriate mandate and capacities. Again, however, there are setbacks to this approach. ${ }^{35}$ Not in the least it may be difficult for a court to assess the due care that has been taken in the context of a political decision-making process. ${ }^{36}$ In addition, procedural review may conflict with the need for a court to develop substantive standards for fairness that can be taken into account by national decision-making bodies, and it does little to help an individual applicant who is looking for a judgment on the fairness of a decision that has affected his rights. ${ }^{37}$ Furthermore, it is nearly impossible to apply this technique in cases concerning decisions made by others than politically accountable bodies, or in cases where a court is expressly asked to provide a national body with relevant substantive standards. ${ }^{38}$ In the abovementioned AC case, for example, the national court that referred preliminary questions to the CJEU expressly asked for a substantive interpretation of the General Data Protection Regulation and for a set of standards that could help it decide in concrete cases. That clearly advocated against the use of procedural review by the CJEU. Instead, the CJEU had to provide the national court with factors that could be useful for it in deciding on whether it was reasonable for the search engine to be obliged to remove certain search results.

\section{Avoiding Balancing by Instrumentality Review}

In such cases, a third balancing-avoiding strategy can be used, which is that of instrumentality review. ${ }^{39}$ Balancing review concentrates on the choice between either respecting one particular fundamental right or realising another. It is also possible, however, to focus on the choice of a certain measure or decision as a means or instrument to achieve a particular objective. ${ }^{40}$ Instrumentality review, first, implies an examination of the instrument's effectiveness. For example, if it would turn out in the GC case that removing search results does very little to protect individual privacy interests, it would still affect the freedom of information, and that might be untenable. ${ }^{41}$ An important ad-

\footnotetext{
34 The ECtHR is often using this approach in such cases; for a further analysis, see Janneke Gerards, 'Procedural Review by the ECtHR - A Typology' in Gerards and Brems (n 29) 127.

35 For a brief review, see Janneke Gerards and Eva Brems, 'Procedural Review in European Fundamental Rights Cases - Introduction' in Gerards and Brems (n 29) 6; see in more detail Huijbers (n 29) pt III.

36 Cf Huijbers (n 29) ss 7.2.2, 7.3.3 and 7.4.2.

37 Cf Huijbers (n 29) ch 8; Brems (n 34); Björnstjern Baade, 'The ECtHR's Role as a Guardian of Discourse: Safeguarding a DecisionMaking Process Based on Well-Established Standards, Practical Rationality, and Facts' (2018) LJIL, doi:10.1017/S0922156518000110.

38 See also Malu Beijer, 'Procedural Fundamental Rights Review by the Court of Justice of the European Union' in Gerards and Brems ( $\mathrm{n} 29$ ) 177.

39 See Janneke Gerards, 'How to Improve the Necessity Test of the European Court of Human Rights?' (2013) 11 ICON 466 and Eva Brems and Laurens Lavrysen, “Don't Use a Sledgehammer to Crack a Nut': Less Restrictive Means in the Case Law of the European Court of Human Rights' (2015) 15 HRLR 139.

40 Gerards (n 40) 470; Ian Turner, 'Judicial Review, Irrationality and the Review of Merits' (2006) 37 NLJ $37,40$.

41 Denise Réaume, 'Limitations on Constitutional Rights: The Logic of Proportionality' (University of Oxford Legal Research Paper Series, Paper no 26/2009) <http://ssrn.com/abstract=1463853>
} 
vantage of such effectiveness review is that the suitability of a certain means can be established based on empirical data, and it does not require as many normative and subjective choices to be made as balancing does. ${ }^{42}$ Second, instrumentality review can be about the necessity of using a certain means to achieve a particular objective. ${ }^{43}$ There are different versions of this necessity test, but its best-known manifestation is the 'least intrusive means test' ${ }^{44}$ This test is sometimes described as not trying to use a cannon to kill a mosquito, or a sledgehammer to crack a nut. ${ }^{45}$ Put differently, if a certain aim can be achieved by using an alternative that would do less harm to individual rights, the alternative would be the more reasonable choice. In the GC case, for example, if it would be possible to conceive of alternatives to removing all search results that would do less harm to the right to freedom of information and that would be just (or nearly) as protective of the right to be forgotten, those alternatives should be chosen.

In practice, the CJEU usually favours instrumentality review over balancing review. ${ }^{46}$ In many of this Court's judgments on conflicts between rights and interests, it uses the formula that a contested measure should be effective and (strictly) necessary to achieve a legitimate objective of general interest. ${ }^{47}$ Indeed, also in $A C$, the CJEU emphasised that displaying the results of a search by a search engine should be 'strictly necessary for protecting the freedom of information' ${ }^{48}$ In line with this, the CJEU defined an alternative to removing all search results for cases about matters that could be of interest to the public, such as cases where the search results refer to publications about criminal court cases. In that situation, the operator should be required

to adjust the list of results in such a way that the overall picture it gives the internet user reflects the current legal position, which means in particular that links to web pages containing information on that point must appear in first place on the list. ${ }^{49}$

This consideration also can be regarded as an example of a search for 'practical concordance' or 'reconciliation'. That means that an alternative is found that does justice to all the interests of the case without one interest necessarily having to outweigh the other. ${ }^{50}$

Importantly, whether a court relies on an effectiveness, a 'least intrusive means test' or test of practical concordance: it does not have to resort to ad hoc balancing. Never-

\footnotetext{
2 Cf Dieter Grimm, 'Proportionality in Canadian and German Constitutional Jurisprudence' (2007) 57 University of Toronto LJ $383,397$.

Gerards (n 40) 470

ibid 481

5 See further on this test Gerards ( $\mathrm{n} 40$ ) 481; Brems and Lavrysen (n 40); Kaplow (n 13). The sledgehammer metaphor was famously used by Lord Diplock of the UK Supreme Court in R. v. Goldstein [1983] 1 WLR 151, 155.

46 See further also Gunnar Petursson, The Proportionality Principle as Tool for Disintegration in EU Law - of Balancing and Coherence in the Light of the Fundamental Freedoms (Lund University 2014) 137, 148.

47 ibid.

48 GC (n 5) para 69.

49 ibid para 78

50 See further eg Gerards (n 40) 247. On the German notion of 'praktische Konkordanz', see further eg Marcus Schladebach, 'Praktische Konkordanz als verfassungsrechtliches Kollisionsprinzip. Eine Verteidigung' [Practical Concordance as constitutional collision principle. A defence]' (2014) 53 Der Staat 263, 271.
} 
theless, such reliance on instrumentality review may have its problematic sides. ${ }^{51}$ To name but a few, it is difficult to define to any amount of clarity how 'effective' a certain means should be, or whether and how a court would be able to determine which alternative means are available to achieve a certain outcome. ${ }^{52}$ Thus, instrumentality review does not present a full and ready substitute for balancing review either. Generally, however, if applied systematically and responsibly, instrumentality review may limit the number of cases in which a court has to engage in ad hoc balancing. ${ }^{53}$

\section{The Age of Balancing Revisited?}

Given the attractiveness of the balancing metaphor, and in light of the considerable difficulties alternative approaches bring along, it is not surprising that balancing review is still popular with many courts and scholars. ${ }^{54}$ Even so, it has been shown in this opinion that the alternative approaches have the advantage of inviting a line of judicial reasoning that is more comprehensible, clear, precise and fact-based than open, ad hoc balancing is. In addition, it is clear that such alternatives are increasingly often applied by courts dealing with conflicting fundamental rights - the ECtHR, for example, often relies on substantive standard-setting and procedural review, whereas the CJEU frequently resorts to instrumentality review. This shows that the continued popularity of balancing should not obscure that we seem to be entering an age where balancing is just one option for judicial argumentation out of many, and where other techniques are readily available that can be and are used to provide transparent and clear reasoning. That should be regarded as a positive development indeed.

51 See further eg Gerards (n 40); Brems and Lavrysen (n 40); Rivers (n 11).

52 See in much more detail Gerards (n 40).

53 Gerards (n 40).

54 See in particular eg Möller (n 14). 